\title{
Современные производственные факторы, определяющие биологическую и экономическую эффективность хранения картофеля
}

\author{
Зейрук Владимир Николаевич \\ ФГБНУ ВНИИ картофельного хозяйства имени А.Г. Лорха \\ Адрес: 140051, Московская область Люберецкий район, п. Красково, ул. Лорха, дом 23, литера «В» \\ E-mail: vzeyruk@mail.ru
}

\begin{abstract}
Мальцев Станислав Владимирович ФГБНУ ВНИИ картофельного хозяйства имени А.Г. Лорха Адрес: 140051, Московская область Люберецкий район, n. Красково, ул. Лорха, дом 23, литера «В» E-mail:vzeyruk@mail.ru
\end{abstract}

\begin{abstract}
Васильева Светлана Викторовна
ФГБНУ ВНИИ картофельного хозяйства имени А.Г. Лорха Адрес: 140051, Московская область Люберецикий район, п. Красково, ул. Лорха, дом 23, литера «В»

E-mail:vzeyruk@mail.ru
\end{abstract}

Бызов Василий Аркадьевич

ВНИИК - филиал ФГБНУ «ФНЦ пищевых систем им. В. М. Горбатова» РАН Адрес: 140051, Московская область, Люберецкий район, n. Красково, ул. Некрасова, дом11

E-mail: law.arrisp@fncps.ru

\begin{abstract}
В статье приведено влияние различных факторов на потери при хранении картофеля в Центральном регионе России. Особое внимание уделено величине потерь от механических повреждений, их влияние на показатели: естественная убыль массы картофеля, технический отход, ростки и абсолютная гниль.

Показана положительная роль использования обработки клубней химическими и биологическими препаратами, такими как Максим, Агат 25K, Вист.

Дан анализ затрат энергоресурсов и роль логистики. Приведено сравнение затрат электроэнергии в простейших и современных картофелехранилищах. Авторами разработана и внедрена система активной вентиляции «Агро-7-Микроклимат» с автоматическим поддержанием оптимальных температурновлажностных режимов микроклимата.
\end{abstract}

Ключевые слова: картофель; хранилище; потери; технологии закладки; биологические препараты; химические препараты; температура; относительная влажность; активная вентиляция; энергозатраты

\section{Введение}

В понятие эффективности технологии хранения картофеля входят, по большому счету, две основные составляющие - потери продукции и затраты энергоресурсов, которые в свою очередь зависят от целого ряда факторов. Потери зависят от степени поражения клубней болезнями, их распространенности в период вегетации, а также нанесенных механических повреждений при уборке и закладке на хранение, продолжительности периода покоя, устойчивости к патогенам возделываемых сортов.

В настоящее время в России на картофеле насчитываетсяболее 40 наиболеераспространенных болезней, ежегодные потери урожая от которых составляет от 10 до 30\%. Из-за них происходит потеря качества и снижается пригодность к хранению. Потери при хранении в хозяйствах всех 
категорий России могут оцениваться на уровне 1,5 млн. т, экспортные поставки - 150-200 тыс. т. (Жевора, 2019, с.2-7; Жевора, 2018, с. 3-16).

Потери только от клубневых гнилей достигают 30 - 50\% (Дорожкин, Бельская, 1979, с.314; Дорожкин, 1989, с. 134). Особенно большой ущерб наносит совместное действие грибов и бактерий, относящихся к более, чем 30 родам (Дорожкин, 1980 , с. 63-64).

Снижение влияния отрицательных факторов на хранящиеся клубни, обеспечение их высокого качества, сведение до минимума потерь при совершенствовании предуборочных и в процессе основного хранения приёмов, влияющих на их период покоя, задача современных технологий хранения картофеля (Пшеченков, 2007, с. 192; Савина, 2009, с. 208).

В последние годы значительно возросли объёмы картофеля идущего на промышленную переработку, где требуется своя специфика, связанная с технологией производства и хранения (Старовойтов, 1998, с. 2; Старовойтов, 2001, с. 114119; Симаков, Анисимов, Старовойтов, 2006, с. 153; Тульчеев, Лукин, 2008, с. 67-70).

Процессы защиты культуры картофеля и его хранения тесно взаимосвязаны и представляют единый технологический процесс. Поэтому в современных условиях для дальнейшего роста и развития картофелеводства и получения качественной продукции в Центральном регионе РФ, решение проблемных вопросов технологии защиты и хранения является актуальной задачей.

Целью наших исследований являлось усовершенствованиетехнологииуборки ихранения картофеля различного назначения в Центральном регионе России. В процессе работы была проведена оценка влияния различных способов уборки картофеля (поточная и прямоточная технологии) на величину механических повреждений клубней и их лежкость при длительном хранении; выявлена эффективность использования различных химических и биологических препаратов, обеспечивающих снижение потерь картофеля при хранении. Полученные данные в дальнейшем могут быть применены при строительстве новых, реконструкции имеющихся картофелехранилищ, a также оснащении их энергоэффективной системой активной вентиляции с автоматическим поддержанием оптимальных параметров микроклимата.
Исследования проводились на базе трех хозяйств в Московской области:

- Экспериментальная база «Коренево» (Люберецкий район). Почва дерновоподзолистая, супесчаная. Хранение картофеля осуществляется в холодных камерах;

- $\mathrm{AO}$ «Озеры» (Озерский район). Картофель хранится в картофелехранилище арочного типа вместимостью 2000 тонн;

- ООО «Таширово» (Наро-Фоминский район). Почва дерново-подзолистая тяжелосуглинистая. Картофелехранилища кирпичные вместимостью по 1000 тонн.

\section{Методика}

Bсе проводимые исследования осуществляли в соответствии с авторскими методиками специалистов института ФГБНУ ВНИИКХ: Методические указания по технологии хранения картофеля различного назначения (Пшеченков, Зейрук, Сидякина, Гудкова, Сазонова, 2002, с. 20); Методические указания по оценке сортов картофеля на пригодность к переработке и хранению (Пшеченков, Давыденкова, Седова, Мальцев, 2008, с. 16-17; Пшеченков, Давыденкова, Седова, Мальцев, 2010, с. 30).

Методические указания по оценке селекционного материала картофеля на устойчивость клубней к механическим повреждениям (Филина, Яшина, 1978, с. 9). Аналитические исследования выполняли в лаборатории хранения и переработки картофеля, агрохимии и биохимии ФГБНУ ВНИИКХ.

Температура и относительная влажность воздуха (ОВВ) при хранении картофеля. В опытах, проводимых в холодильных камерах ФГБНУ ВНИИКХ картофель хранили при температурах $2-4^{\circ} \mathrm{C}$ и $5-7^{\circ} \mathrm{C}$. В картофелехранилищах $\mathrm{AO}$ «Озеры» температура хранения в зависимости от назначения картофеля поддерживалась на уровне $2-4,5-7^{\circ} \mathrm{C}$ и $8-10^{\circ} \mathrm{C}$; в картофелехранилищах $\mathrm{OOO}$ «Таширово» $-2-4^{\circ} \mathrm{C}$. ОВВ во всех случаях в основной период хранения поддерживалась на уровне 90$95 \%$.

Лежкость клубней при хранении (сентябрь-апрель) с определением общихотходов, естественнойубыли массы, абсолютной гнили и технического отхода, потерь на ростки определяли по методическим указаниям ВАСХНИЛ (Пшеченков, Зейрук, Еланский, Мальцев, 2007, с. 192). Для определения этих показателей на хранение закладывали сетки с 
клубнями массой 5 кг в пятикратной повторности. При крупнотоварном производстве картофеля в условиях $\mathrm{AO}$ «Озеры» сетки размещались в арочных хранилищах равномерно в пяти зонах на глубине $30 \mathrm{~cm}$.

Обработка препаратами осуществлялась с использованием системы активной вентиляции методом продува распыленного аэрозоля через насыпь картофеля.

Биохимические и потребительские показатели клубней, а также величину отходов при механической очистке клубней определяли в соответствии с методическими указаниями по оценке сортов картофеля на пригодность к переработке и хранению (Кирюхин, Ладыгина, Князева, 1980, с. 44; Кирюхин, Ладыгина, Чиолина, 1989, с. 142;Пшеченков, Зейрук, Еланский, Мальцев, 2007, с. 192; Тульчеев, Лукин, 2008, с. 67-70).

\section{Результаты и обсуждение}

В процессе исследований нами был проведен учет энергоресурсов - от конструктивных особенностей и отдаленности хранилища до полей выращивания и системы вентиляции.

Рассмотрим влияние на потери при хранении наиболее вредоносной болезни картофеля фитофтороза. Прежде всего, надо определить по характеристикам наиболее устойчивые сорта (Дорожкин, Бельская, 1979, с.314; Дорожкин, Бельская, Викторчик, Алексеева, Новикова, 1989, c.134).

По данным наших многолетних исследований при содержании в насыпи картофеля клубней пораженных фитофторозом от 5 до 7\% потери при хранении в течение 180-240 суток составили $12-15 \%$, а потери урожая - при поражении ботвы в пределах 50-70\% до 15-20\%, при 50-100\% до 30$50 \%$ в зависимости от сорта. Из этого следует, что общие потери в денежном выражении составляют значительную сумму. Для их снижения, по нашим данным, в условиях Центрального региона России в период вегетации растения необходимо обрабатывать соответствующими препаратами не менее 5-6 раз в зависимости от сорта и погодных условий. Затраты на обработку в период вегетации полностью окупаются прибавками урожая и снижением потерь в процессе хранения. При наличии поражения клубней фитофторозом необходимо повысить интенсивность и продолжительностьнепрерывноговентилирования наружным воздухом при подсушивании клубней по мере загрузки картофеля в хранилище до $150 \mathrm{~m}^{3} / \mathrm{T}$ в час и в течение 2 суток, как это рекомендуется при закладке на хранение непораженного фитофторозом картофеля с интенсивностью до $100 \mathrm{~m}^{3} / \mathrm{T}$ в час. В лечебный период повышается количество включений вентиляторов по одному часу 6-7 раз в сутки, вместо 4-5 раз по 0,5 часа рециркуляционным воздухом при относительной влажности воздуха $80-85 \%$ и температуре $16-18^{\circ} \mathrm{C}$.

Прежде всего, необходимо выполнить требования, предъявляемые к картофелю, закладываемому на длительное хранение в соответствии с ГОСТ Р 339966 - 2016. Поэтому в идеале они должны быть абсолютно здоровыми, без механических повреждений мякоти и кожуры, без подмораживания и других дефектов. Однако на практике такого не бывает. Механические повреждения клубней оказывают существенное влияние на величину потерь при хранении, особенно такие виды - как естественная убыль массы (испарение и дыхание) и технический отход, вызываемый различными видами сухих и мокрых гнилей, трещинами и вырывами мякоти клубней (Дорожкин, 1980, с. 63-64; Жевора, 2019, с.2-7; Жевора, 2018, 3-16). Эти процессы во многом зависят от сорта, условий вегетации, способа, срока уборки и технологии закладки картофеля на хранение.

Потери от повреждений мякоти и обдира кожуры формируются в основном температурой почвы во время уборки (Рисунок 1) и технологией закладки картофеля на хранение - по пото́чной или прямоточной (Таблица 1).

Пото́чная - это технология с осенним сортированием: комбайн - сортировальный пункт с бункерами-накопителями - транспортировка в хранилище, а прямоточная - без осеннего сортирования: комбайн - транспортное средство хранилище.

Полученные нами данные доказывают, что наименьшие механические повреждения и потери при хранении наблюдаются при поточной технологии уборки и закладки в хранилище.

Из рисунка следует, что чем ниже температура почвы, тем выше повреждения, особенно мякоти клубня. Поэтому картофель, убранный в поздние сроки, хранится со значительно большими потерями,посравнениюсубранным в оптимальные сроки. По нашим данным в зависимости от 
метеоусловий года разница составляет от 7-9\% до $12-14 \%$, особенно при сочетании высокой относительной влажности почвы 92-94\% с более низкой ее температурой $\left(1-3^{\circ} \mathrm{C}\right)$. Зрелость клубня определяется степенью обдира кожуры. В условиях Центрального региона России при выращивании картофеля на суглинистых почвах для снижения обдиракожурыиповреждениямякотиобязательным приемом является предуборочное удаление ботвы комбинированным способом за 10-12 дней до начала уборки. Сначала проводят десикацию ботвы одним из препаратов (Суховей, Реглон Форте (1,02,0 л/га), Баста (2,0-2,5 л/га), а затем, на шестойседьмой день, скашивают её ботводробителем. Это обеспечивает чистую поверхность гребней, в связи с чем почва в них быстрее прогревается и просыхает, утолщается субериновый слой в клубне и быстрее образуется раневая перидерма и исключается контакт зараженной ботвы с клубнями.
Потери при хранении также во многом зависят от технологии загрузки картофеля в хранилище (Таблица 1). Общие потери значительно ниже при прямоточной технологии уборки (Дорожкин, 1980, с.63-64; Карманов, 1983, с.14).

Результаты исследований, представленные в таблице 1, доказывают, что при применении прямоточной технологии уборки картофеля происходит снижение суммарных механических повреждений клубней практически в три раза. Это отмечено по всем видам механических повреждений: обдиру кожуры, трещинам, вырывам, порезам и потемнением мякоти. Особенно важно, что процент общих потерь за 8 месяцев хранения (убыль массы, технический отход, абсолютная гниль и ростки) также значительно меньше при прямоточной технологии уборки. Для промышленной переработки картофеля
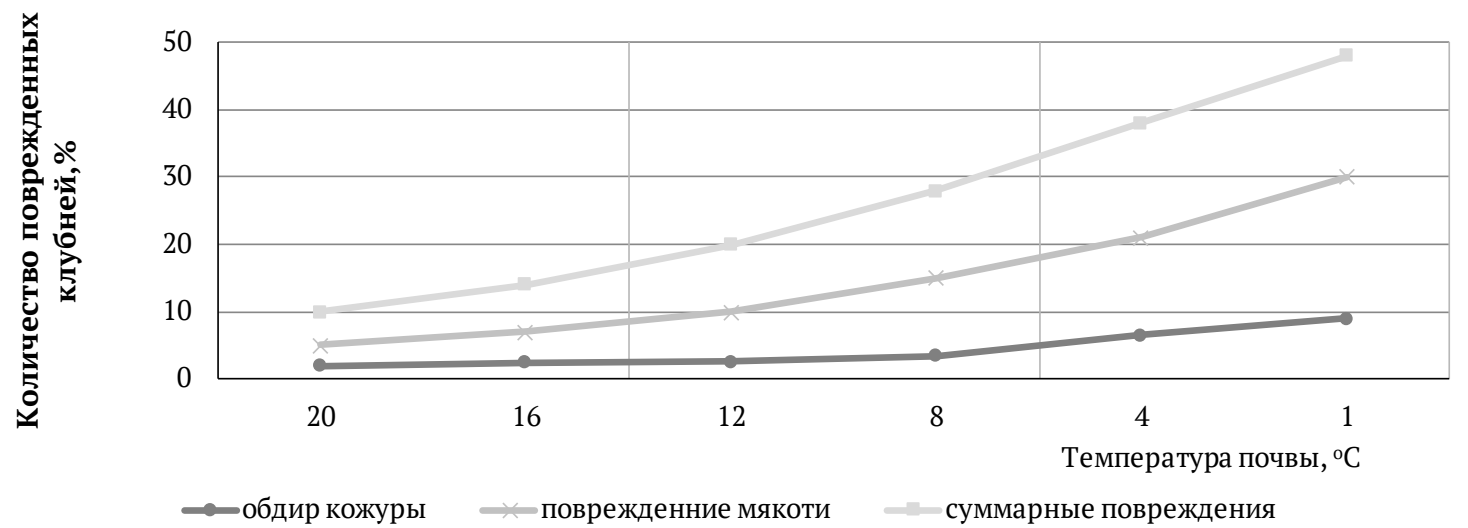

Рисунок 1. Зависимость механических повреждений клубней при уборке комбайном от температуры почвы.

Таблица 1

Механические повреждения клубней и потери при хранении в зависимости от технологии загрузки картофеля в хранилище при уборке комбайном (усредненные обобщенные данные за несколько лет по ряду сортов)

\begin{tabular}{|c|c|c|}
\hline \multirow{2}{*}{ Наименование показателей } & \multicolumn{2}{|c|}{ Технология } \\
\hline & Пото́чная & Прямоточная \\
\hline $\begin{array}{l}\text { 1. Суммарные механические повреждения клубней, \% } \\
\text { в том числе: }\end{array}$ & 66,0 & 20,2 \\
\hline $\begin{array}{l}\text { Обдир кожуры } \\
\text { - до } 1 \frac{12}{2} \text { поверхности клубня } \\
\text { - более } 1 \frac{2}{2} \text { поверхности клубня }\end{array}$ & $\begin{array}{l}16,5 \\
21,6\end{array}$ & $\begin{array}{l}5,5 \\
4,6\end{array}$ \\
\hline Трещины, вырывы и порезы мякоти & 12,3 & 3,9 \\
\hline Потемнение мякоти от ударов & 16,0 & 6,2 \\
\hline $\begin{array}{l}\text { 2. Общие потери за } 8 \text { месяцев хранения, \% } \\
\text { в том числе: } \\
\text { - убыль массы (потери на дыхание) } \\
\text { - технический отход (сухая гниль) } \\
\text { - абсолютная гниль } \\
\text { - ростки }\end{array}$ & $\begin{array}{c}32,2 \\
16,0 \\
11,0 \\
4,0 \\
1,2\end{array}$ & $\begin{array}{l}14,3 \\
5,5 \\
7,5 \\
1,0 \\
0,3\end{array}$ \\
\hline 3.Отходы при очистке клубней, \% & 28,0 & 15,0 \\
\hline
\end{tabular}


и экологической чистоты окружающей среды существенно, что отходы при очистке клубней снижаются практически в 2 раза.

Снижению потерь при хранении способствует также осенняя обработка клубней при закладке на хранение химическими и биологическими препаратами (Дорожкин, Бельская, Викторчик, Алексеева, Новикова, 1989, с.134; Колошеин, 2017, с.19; Пшеченков, 2019, с.128; Пшеченков, 2017, с. 23; Савина, 2009, с. 208). Так, обработка раствором препарата Максим, 2,5\% в количестве 0,2 л/т сократила общие потери за 9 месяцев хранения на 9,8\% по сравнению с контролем, в том числе естественную убыль массы на 3,5\%; биологическим препаратом Агат-25K при расходе рабочего раствора 5,0 л/т на 4,6\%, убыль массы на 1,3\%. Наиболее эффективным оказался дымовой фунгицид в виде шашки Вист (Пшеченков,2007, c. 192), отличающийся простой технологией применения в течение всего периода хранения через систему автоматически регулируемой активной вентиляции. Максимальный эффект получен при вентиляции рециркуляционным воздухом насыпи картофеля в лечебный период. В этот период, обработка Вистом в дозе 10 г/т снизила общие потери на 10,1\%, в том числе убыль массы за период хранения - сентябрь-май на 5,8\%. В расчете на хранилище, например, вместимостью 1000 т. обработка Вистом сохраняет около 100 тонн картофеля, что в денежном выражении при цене 10 руб./кг составляет 1,0 млн. руб. при стоимости обработки 82 тыс. руб., т.е. чистая прибыль составляет с 1000 т. свыше 900 тыс. руб.

Кроме указанных факторов, убыль массы при хранении также зависит от относительной влажности воздуха в хранилище (OBB). По данным многих авторов она должна быть на уровне 90-95\%, а в лечебный период на уровне 95-98\%, поскольку клубни в этот период при низкой влажности интенсивно дышат, например, при уровне 7580\% потери только за первые 20-25 суток могут составить 2,5-3,0\%, не считая потерь в осенний период хранения.

В механически поврежденных клубнях убыль массы на 2-3\% выше, по сравнению с неповрежденными, а при пониженной влажности на 4-5\% (Таблица 2).

Транспортировка картофеля с поля, закладка его на хранение и сам процесс хранения связаны с определенными затратами энергоресурсов, цена на которые постоянно растет. Затраты на перевозку картофеля также зависит от урожайности и удаленности полей от места хранения.

Во многих хозяйствах расстояние перевозки нередко составляет от 10-15 до 20-25 и более километров. При расстоянии, например, 20 км и урожайности 40 т/га затраты на перевозку самосвалом КамАЗ составляют около 140,0 тыс. руб., т.е. 3,5 тыс. руб. на гектар или 78 руб./т (усредненные расчетные данные экономистов крестьянского хозяйства «Нива», Ивановская обл.). При уборке с площади 100 га затраты уже достигают - 350,0 тыс. руб. - 500 га - 1,75 млн руб. Для снижения таких расходов продовольственный картофель следует выращивать в специализированном картофельном севообороте, расположенном вблизи места хранения продукции. Очень большую роль играет тип картофелехранилища, место расположения, система вентиляции и правильная их реконструкция (4). Поэтому при выборе места строительства базы хранения, кроме прочих факторов, необходимо также учитывать возможность создания вокруг неё в будущем специализированного севооборота. Это относится

Таблица 2

Убыль массы при хранении в зависимости от уровня механических повреждений клубней и ОВВ (обобщенные данные по среднеранним сортам, температура хранения $\left.3-4^{\circ} \mathrm{C}\right)$

\begin{tabular}{|c|c|c|c|}
\hline \multirow{3}{*}{ Уровень механических повреждений клубней, \% } & \multirow{3}{*}{ ОВВ в хранилище, \% } & \multicolumn{2}{|c|}{ Убыль массы,\% } \\
\hline & & \multicolumn{2}{|c|}{ Срок хранения } \\
\hline & & Сентябрь-январь & Сентябрь-май \\
\hline \multirow{2}{*}{ Контроль - клубни без повреждений } & $73-75,0$ & 3,8 & 5,9 \\
\hline & $93-95,0$ & 2,7 & 4,1 \\
\hline \multirow{2}{*}{10,0} & $73-75,0$ & 5,6 & 9,3 \\
\hline & $93-95,0$ & 4,2 & 7,2 \\
\hline \multirow{2}{*}{17,0} & $73-75,0$ & 6,9 & 10,8 \\
\hline & $93-95,0$ & 5,4 & 8,9 \\
\hline \multirow{2}{*}{25,0} & $73-75,0$ & 8,0 & 11,9 \\
\hline & $93-95,0$ & 6,9 & 10,0 \\
\hline
\end{tabular}


и к существующим хранилищам, которые в настоящее время располагаются на больших расстояниях от полей с возделыванием в универсальныхсевооборотах.Специализированный севооборот позволяет сократить потребность в транспортных средствах в напряженный уборочный период.

Помимо затрат на транспортировку длительное хранение картофеля связано с определенными затратамиэлектроэнергии,тарифынакоторуютакже постоянно растут. Они зависят от применяемого вентиляционного оборудования, системы активной вентиляции, способа поддержания оптимальных температурно-влажностных параметров микроклимата в хранилище, и ряда других факторов. Кроме затрат на вентиляцию, значительный расход электроэнергии идет на обогрев хранилища, который зависит от погодных условий и типа хранилища. Наименьший - в заглубленных хранилищах, построенных во многих хозяйствах в бывшем Советском Союзе. В таких хранилищах в весенний период долго сохраняется необходимая температура хранения, что важно для семенного картофеля, а зимой требуется намного меньший обогрев по сравнению с напольными хранилищами, широко применяемыми в настоящее время (Кирюхин, Ладыгина, Князева. 1980, с.44).

В своих исследованиях мы сравнивали затраты электроэнергии на тонну хранимого картофеля и несколько систем управления - от простейших, приводимых вручную с помощью задвижек, до современных с автоматическим поддержанием оптимальных параметров микроклимата в хранилище. Результаты показали, что управление вручную с помощью задвижек можно рекомендовать для применения в фермерских хозяйствах с выращиванием небольших объемов картофеля, для которых требуется хранилище на 200-300 т. с минимальной стоимостью на электроэнергию. Здесь делается смесительная камера сечением 1,5 x 1,5 м на основе деревянного каркаса из бруса 100 х 100 мм, обшитого 10-12 мм фанерой. В верхней части к ней подводятся два воздуховода - приточный и рециркуляционный сечением 800 х 800 мм, изготовленные из металла или из досок, в которые вставляются задвижки для регулирования подачи воздуха. В нижней части камеры устанавливается осевой вентилятор малой мощности, подающий воздух в магистральный канал и далее в распределительные каналы. В торцевой стене под потолком делается вытяжное отверстие с клапаном. В таких хранилищах удельный расход электроэнергии не превышает 5-8 кВт/ч на тонну, включая обогрев.
Хранилища большой вместимостью, строящиеся из различных материалов, и различной конструкции оборудуются сложной системой активной вентиляции с автоматическим поддержанием оптимальных температурновлажностных режимов микроклимата. При этом используются в основном системы различных зарубежных фирм. Анализ их работы показал, что удельные затраты электроэнергии колеблются в большом диапазоне - от 25-30 до 45-50 кВт/ч на тонну, не считая обогрева, что делает процесс хранения более дорогим. Исходя из этого, нами была разработана и внедрена в ряде хозяйств Московской, Тверской, Ульяновской, Смоленской, Рязанской, Калужской и ряде других областей, а также в Якутии система «АГРО-7-Микроклимат» при строительстве новых и реконструкции старых хранилищ, переоборудовании складских помещений и животноводческих ферм. Она базируется на использовании малогабаритных, энергосберегающих центробежных вентиляторов с регулируемым числом оборотов производства фирмы Ebm-papst (Германия) с приводом от постоянного тока через встроенный преобразователь и приточно-вытяжных и рециркуляционных клапанах жалюзийного типа с электроприводом. В зависимости от периода хранения и состояния картофеля вентиляторы могут работать в соответствии с заданным алгоритмом от $25-30 \%$ до $100 \%$ мощности. Это обеспечивает минимальное потребление электроэнергии на весь процесс хранения. Система работает при хранении навалом, в закромах и контейнерах, как при хранении картофеля, так и других с/х культур, в частности лука и моркови.

Пять лет научного и производственного опыта эксплуатации картофелехранилищ показал, что в зависимости от метеорологических условий и качества исходного материала, закладываемого на хранение, удельный расход электроэнергии составляет от 10-12 до 16-18 кВт/ч на тонну при потерях, не превышающих установленных ГОСТом норм - 6-7\% за 8-9 месяцев хранения.

\section{Заключение}

Таким образом, для лучшей сохранности и экономической целесообразности необходимо закладывать картофель на длительное хранение по прямоточной технологии уборки. Следует использовать при этом обработку клубней химическими и биологическими препаратами Максим, Агат 25K, Вист, а также с целью сохранения 
энергозатрат внедрять в производство систему активной вентиляции «Агро-7-Микроклимат» с автоматическим поддержанием оптимального температурно-влажностного режима.

\section{Литература}

Дорожкин Н.А., Бельская С.И. Болезни картофеля. Минск: Наука и техника, 1979. 314 с.

Дорожкин Н.А., Бельская С.И., Викторчик И.В., Алексеева Т.П., Новикова В.В. Клубневые гнили картофеля. Минск: Наука и техника, 1989. 134 с.

Дорожкин Н.А. Взаимосвязь бактерий и грибов в патогенезе клубневых гнилей / В кн.: Тезисы докладов Всесоюзного совещания. -1980. -С. $63-64$.

Жевора С.В., Анисимов Б.В., Симаков Е.А., Овэс Е.В., Зебрин С.Н. Картофель: проблемы и перспективы // Картофель и овощи. 2019. № 7. C. 2-7.

Жевора С.В., Анисимов Б.В., Овэс Е.В., Янюшкина Н.А. Картофелеводство России: итоги, прогнозы, приоритеты развития отрасли // Мат. научн. практ. конф. «Современное состояние и перспективы развития селекции и семеноводства картофеля», 9-10 июля 2018 г. М.: ФГБНУ ВНИИКХ, 2018. С. 3-16.

Зейрук В.Н. Разработка и совершенствование технологического процесса защиты и хранения картофеля в Центральном регионе РФ: Автреф. дисс. на соискание докт. с.-х. наук. М., 2015. 44 с.

Карманов С.Н., Кустарев А.И., Назаренко Б.П., Черникова М.Ф., Яшина И.М. Методические указания по экологическому сортоиспытанию картофеля. М.: ВАСХНИЛ, 1983. 14 с.

Колошеин Д.В. Снижение потерь картофеля и энергопотребления системы вентиляции картофелехранилища совершенствованием воздуховода: автореферат диссертации на соискание ученой степени кандидата технических наук. Рязань, 2017. 19 с.

Кирюхин В.П., Ладыгина Е.А., Князева В.П. Методические указания по определению углеводов и витаминов в картофеле. М.: ВАСХНИЛ, 1980.44 с.

Кирюхин В.П., Ладыгина Е.А., Чиолина М.М., Парфенова А.В. Методика физиологобиохимических исследований картофеля. М.: ВНИИКХ, Госагропром, 1989. 142 с.

Максимова Е. Строительство хранилищ - в начале пути.В России нехватает современных складских мощностей на 5,0 млн. т. // Агроинвестор. 2017.
№ 11. C. 23-28.

Пшеченков К.А., Сидякина И.И., Зейрук В.Н., Гудкова П.П., Сазонова 3.В. Методические указания по технологии хранения картофеля различного назначения. М.:ВНИИКХ, 2002. 20 с.

Пшеченков К.А., Мальцев С.В. Методические рекомендации по технологии хранения различных сортов картофеля. М.: ВНИИКХ, 2010. $30 \mathrm{c}$.

Пшеченков К.А., Сидякина И.И., Зейрук В.Н., Давыденкова О.Н., Анисимов Б.В., Савенко В.Г. Современные технологии хранения картофеля. М.: ФГНУ «Росинформагротех», 2004. 56 с.

Пшеченков К.А., Зейрук В.Н., Еланский С.Н., Мальцев С.В. Технологии хранения картофеля. М.: Картофелевод, 2007. 192 с.

Пшеченков К.А., Давыденкова О.Н. Эксперессметод определения содержания редуцирующих сахаров // Картофель и овощи. 2008. № 7. С.16-17.

Пшеченков К.А., Зейрук В.Н., Еланский С.Н., Мальцев С.В., Прямов С.Б. Хранение картофеля. М.: "Агроспас", 2016. 128 с.

Пшеченков К.А., Мальцев С.В., Зейрук В.Н., Сазонова 3.В., Клюев С.И. Современные технологии хранения картофеля / Под общ. ред. Б.В. Анисимова. Чебоксары: ВНИИКХ, 2017. 23 с.

Савина О.В. Новые приёмы в технологии производства и хранения картофеля. Рязань: РГАТУ, 2009. 208 c.

Симаков Е.А., Анисимов Б.В., Старовойтов В.И., Пшеченков К.Л., Зейрук В.Н., Суровцев Р.А. Переработка картофеля - стратегический путь развития картофелеводства России. М.: ВНИИКХ, 2006. 153 с.

Старовойтов В.И., Перфильева С.Д., Черников В.И. Пневматический сборщик насекомых ПСН-2,8 в борьбе с колорадским жуком // Информационный листок. 1998. № 108-98. С. 2.

Старовойтов В.И. Требования к картофелю, предназначенному для переработки // В кн.: Качество картофеля и картофелепродуктов / Под редакцией А.В. Коршунова. М.: ВНИИКХ, 2001. С. 114-119.

Тульчеев В.В., Лукин Н.Д. Рынок картофеля и продуктов его переработки: состояние, проблемы, перспективы // Экономика сельскохозяйственных и перерабатывающих предприятий. 2008. № 8. С. 67-70 .

Филина Н.И., Яшина И.М. Методические указания по оценке селекционного материала картофеля на устойчивость клубней к механическим повреждениям. М.: ВНИИКХ, 1978.9 с.

Шпаар Д., Быкин А., Дрегер Д.. Картофель. М.: ООО «ДЛВ Агродело», 2010. 458 с. 


\title{
Modern Production Factors that Determine the Biological and Economic Efficiency of Potato Storage
}

\author{
Vladimir N. Zeyruk \\ Lorch Potato Research Institute \\ 24 “B”, Lorch str., Kraskovo, Lyubertsy district, Moscow Region, 140051, Russian Federation \\ E-mail:vzeyruk@mail.ru
}

Stanislav V. Maltsev

Lorch Potato Research Institute

24 “B”, Lorch str., Kraskovo, Lyubertsy district, Moscow Region, 140051, Russian Federation

E-mail:vzeyruk@mail.ru

Svetlana V. Vasilyeva

Lorch Potato Research Institute

24 “B”, Lorch str., Kraskovo, Lyubertsy district, Moscow Region, 140051, Russian Federation

E-mail:vzeyruk@mail.ru

\begin{abstract}
Vasily A. Byzov
All-Russian Research Institute for Starch Products - Branch of V.M. Gorbatov Federal Research Center for Food Systems of the RAS

11, Nekrasovka str, Kraskovo, Lyubertsy district, Moscow Region, 140051, Russian Federation E-mail:law.arrisp@fncps.ru
\end{abstract}

\begin{abstract}
The article presents the influence of various factors on potato storage losses in the Central region of Russia. Particular attention is paid to the magnitude of losses from mechanical damage, their impact on the indicators: the natural loss of potato mass, technical waste, sprouts and absolute rot.

The positive role of the use of treatment of tubers with chemical and biological preparations such as Maxim, Agate $25 \mathrm{~K}$, Whist is shown.

The analysis of energy costs and the role of logistics. The comparison of electricity costs in the simplest and modern potato storage facilities is given. The authors developed and implemented the system of active ventilation "Agro-7Microclimate" with automatic maintenance of optimal temperature and humidity conditions of the microclimate.
\end{abstract}

Keywords: potatoes; storage; mechanical damage; microclimate; relative humidity; losses; technology bookmarks; energy costs

\section{References}

Dorozhkin N.A., Belskaya S.I. Bolezni kartofelya [Potato diseases]. Minsk: Publ. Nauka i tekhnika, 1979. $314 \mathrm{p}$.

Dorozhkin N.A., Belskaya S.I., Viktorchik I.V., Alkseeva T.P., Novikova V.V. Klubnevye gnili kartofelya [Tuber rot of potato]. Minsk: Nauka i tekhnika, 1989. $134 \mathrm{p}$.

Dorozhkin N.A. Vzaimosvyaz bakterij i gribov v patogeneze klubnevyh gnilej [The relationship of bacteria and fungi in the pathogenesis of tuberous rot]. In Tezisy dokladov Vsesoyuznogo soveshchaniya [Abstracts of the all-Union meeting], 1980, pp. 63-64.
Zhevora S.V., Anisimov B.V., Simakov E.A., Oves E.V., Zebrin S.N. Kartofel: problemy i perspektivy [Potato: problems and prospects]. Kartofel i ovoshchi / [Potatoes and vegetables], 2019, no.7, pp. 2-7.

Zhevora S.V., Anisimov B.V., Oves E.V., Yanyushkina N.A. Kartofelevodstvo Rossii: itogi, prognozy, prioritety razvitiya otrasli [Potato growing in Russia: results, forecasts, priorities of the industry development]. In Mat. nauchn. prakt. konf. «Sovremennoe sostoyanie $i$ perspektivy razvitiya selekcii i semenovodstva kartofelya» [Proceedings of the scientific and practical conf. "Current state and prospects of potato breeding and seed production"], July 9-10, 2018. Moscow: VNIIKH, 2018, pp. 3-16.

Zejruk V.N. Razrabotka i sovershenstvovanie 
tekhnologicheskogo processa zashchity i hraneniya kartofelya $\mathrm{v}$ Centralnom regione RF. Avtopef. diss. dokt. s.-h. nauk. [Development and improvement of technological process of protection and storage of potatoes in the Central region of the Russian Federation. Abstract of Dr. Sci. (Agriculture) thesis]. Moscow, 2015, 44 p.

Karmanov S.N., Kustarev A.I., Nazarengko B.P., Chernikova M.F., Yashina I.M. Metodicheskieiukazaniya po ekologicheskomu sortoispytaniyu kartofelya [Methodical and instructions on ecological variety testing of potatoes]. Moscow: VASHNIL, 1983, 14 p.

Koloshein D.V. Snizhenie poter kartofelya i energopotrebleniya sistemy ventilyacii kartofelekhranilishcha sovershenstvovaniem vozduhovoda. Avtopef. diss. kand. tekhn. nauk. [Reduction of potato losses and energy consumption of the potato storage ventilation system by improving the air duct. Abstract of Ph.D. (Technology) thesis]. Ryazan, 2017, 19 p.

Kiryuhin V.P., Ladygina E.A., Knyazeva V.P. Metodicheskie ukazaniya po opredeleniyu uglevodov i vitaminov v kartofele [Guidelines for the determination of carbohydrates and vitamins in potatoes]. Moscow: VASHNIL, 1980, 44 p.

Kiryuhin V.P., Ladygina E.A., Chegolina M.M., Parfenova A.V. Metodika fiziologo-biohimicheskih issledovanij kartofelya [Methods of physiological and biochemical studies of potatoes]. Moscow: VNIIKH, 1989, 142 p.

Maksimova E. Stroitelstvo hranilishch - v nachale puti. V Rossii ne hvataet sovremennyh skladskih moshchnostej na 5,0 mln. t. [Construction of storage facilities - at the beginning. Russia lacks modern storage capacity of $5.0 \mathrm{MMT}]$. Agroinvestor, 2017, no. 11, pp. 23-28.

PshechenkovK.A., ZejrukV.N., Sidyakina I.I., Gudkova P.P., Sazonova Z.V. Metodicheskie ukazaniya po tekhnologii hraneniya kartofelya razlichnogo naznacheniya [Methodical instructions on technology of storage of potatoes of different function]. Moscow: VNIIKH, 2002, 20 p.

Pshechenkov K.A., Malcev S.V. Metodicheskie rekomendacii po tekhnologii hraneniya razlichnyh sortov kartofelya [Guidelines for storage technology of different varieties of potatoes]. Moscow: VNIIKH, 2010, 30 p.

Pshechenkov K.A., Sidyakina I.I., Zejruk V.N., Davydenkova O.N., Anisimov B.V., Savenko V.G. Sovremennye tekhnologii hraneniya kartofelya [Modern potato storage technologies]. Moscow: FGNU «Rosinformagrotekh», 2004, 56 p.

Pshechenkov K.A., Zejruk V.N., Elanskij S.N., Malcev S.V. Tekhnologii hraneniya kartofelya [Technology of storage of potatoes]. Moscow: Kartofelevod,
2007, 192 p.

Pshechenkov K.A., Davydenkova O.N. Eksperess-metod opredeleniya soderzhaniya reduciruyushchih saharov [Express method for determining the content of reducing sugars]. Kartofel i ovoshchi [Potatoes and vegetables], 2008, no. 7, pp.16-17.

Pshechenkov K.A., Zejruk V.N., Elanskij S.N., Malcev S.V., Pryamov S.B. Hranenie kartofelya [Potato storage]. Moscow: Agrospas, 2016, 128 p.

18. Pshechenkov K.A., Malcev S.V., Zejruk V.N., Sazonova Z.V., Klyuev S.I. S o v r e m e n n y e tekhnologii hraneniya kartofelya [Modern potato storage technologies]. Ed. by B.V. Anisimov. Cheboksary: VNIIKH, 2017, 23 p.

Savina O.V. Novye priyomy v tekhnologii proizvodstva i hraneniya kartofelya [New techniques in potato production and storage technology]. Ryazan: RGATU, 2009, 208 p.

Simakov E.A., Anisimov B.V., Starovojtov V.I., Pshechenkov K.L., Zejruk V.N., Surovcev R.A. Pererabotka kartofelya - strategicheskij put razvitiya kartofelevodstva Rossii [Potato processing - a strategic way of development of potato production in Russia]. Moscow: VNIIKH, 2006, 153 p.

Starovojtov V.I., Perfileva S.D., Chernikov V.I. Pnevmaticheskij sborshchik nasekomyh PSN-2,8 $\mathrm{v}$ borbe $\mathrm{s}$ koloradskim zhukom [Pneumatic insect collector PSN-2.8 in the fight against the Colorado potato beetle]. Informacionnyj listok [Information sheet]. Moscow: MosoblCNTI, 1998, no. 108-98, p. 2.

Starovojtov V.I. Trebovaniya k kartofelyu, prednaznachennomu dlya pererabotki [Requirements for potatoes intended for processing]. In A.V. Korshunova (ed.) Kachestvo kartofelya i kartofeleproduktov [Quality of potatoes and potato products]. Moscow: VNIIKH, 2001, pp. $114-119$.

Tulcheev V.V., Lukin N.D. Rynok kartofelya i produktov ego pererabotki: sostoyanie, problemy, perspektivy [Potato and processed products market: state, problems, prospects]. Ekonomika selskohozyajstvennyh $i$ pererabatyvayushchih predpriyatij [Economics of agricultural and processing enterprises], 2008, no. 8, pp. 67-70.

Filina N.I., Yashina I.M. Metodicheskie ukazaniya po ocenke selekcionnogo materiala kartofelya na ustojchivost klubnej $\mathrm{k}$ mekhanicheskim povrezhdeniyam [Guidelines for the evaluation of potato breeding material on the resistance of tubers to mechanical damage]. Moscow: VNIIKH, 1978, 9 p.

Shpaar D., Bykin A., Dreger D. Kartofel [Potato]. Moscow: OOO «DLV Agrodelo», 2010, 458 p. 